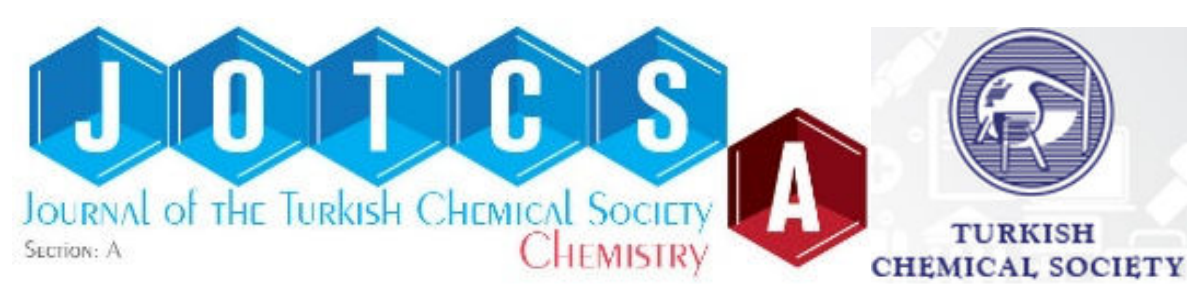

\title{
A Novel Acrylonitrile Derivative Having Photovoltaic Performance
}
Çiğdem Yörür-Göreci ${ }^{*}{ }^{*}$,Mehmet Kazici ${ }^{2}$, Sinem Bozar ${ }^{2}$, Zulal Demir ${ }^{1}$, Abdullah Toraman ${ }^{1}$, Fatih Ongul' ${ }^{2}$, Abid Ali $^{2}$, Serap Güneş ${ }^{2}$
${ }^{1}$ Yildiz Technical University, Faculty of Arts and Sciences, Department of Chemistry, 34210 Istanbul, Turkey

${ }^{2}$ Yildiz Technical University, Faculty of Arts and Sciences, Department of Physics, 34210 Istanbul, Turkey

\begin{abstract}
A new acrylonitrile derivative, 2-(4-bromophenyl)-3-\{5-[2-cyano-2phenylethenyl]furan-2-y/\}acrylonitrile (BPCPFA, 3) which is a potential material for application in organic solar cells, was synthesized by a three-step reaction. The structures of the molecules synthesized in these steps were characterized by using various spectral analyses. BPCPFA was investigated as an electron acceptor molecule in next generation organic solar cells. Theoretical prediction and experimental studies for photovoltaic performance were also performed. Based on these results, it is concluded that BPCPFA with extended conjugated system has good and promising photovoltaic performance with $\mathrm{V}_{\text {oc }}$ value as $0.96 \mathrm{~V}$.
\end{abstract}

Keywords: Conjugated systems; nitriles; organic solar cells; photovoltaics.

Submitted: July 15, 2016. Revised: September 19, 2016. Accepted: September 30, 2016.

Cite this: Yörür-Göreci Ç, Kazıcı M, Bozar S, Demir Z, Toraman A, Ongul F, et al. A Novel Acrylonitrile Derivative Having Photovoltaic Performance. JOTCSA. 2016;3(3):439-52.

DOI: $10.18596 /$ jotcsa.15106.

*Corresponding author. E-mail: cgoreci@hotmail.com. 


\section{INTRODUCTION}

Organic photovoltaics (OPVs) are an encouraging field to produce energy as a renewable energy source. The simple processing, cost-effective fabrication, and device flexibility of organic solar cells make them superior as compared to the inorganic solar cells. Recently, the most popular and efficient way of fabricating organic solar cells is to use the bulk heterojunction concept in which an electron donor and an acceptor is blended in a solution and cast as a film from this solution. The development of bulk heterojunction organic solar cells has shown a fascinating increase in the power conversion efficiency [14].

Despite all this increase, their power conversion efficiency is still low as compared to inorganic solar cells. The most efficient organic solar cells make use of small organic molecules and conjugated polymers in their structure. Most of the small molecules and conjugated polymers used in photovoltaics are mostly p-type (donor) materials $[5,6]$. In this area, the number of materials exhibiting n-type (acceptor) properties is very restricted and among acceptor type molecules the most well-known molecules are fullerenes. For example $[6,6]$-phenyl $C_{61}$ butyric acid methyl ester (PCBM) is a fullerene derivative which has excellent acceptor characteristics. Unfortunately, PCBM also has some disadvantages such as air degradation and cost intensive synthesis $[7,8]$. The need for new acceptor materials for organic photovoltaics is growing rapidly. Consequently, the importance of these materials increases dramatically day by day.

We have synthesized a novel acceptor organic molecule which contains furan ring with electron-withdrawing cyano groups (BPCPFA) and investigated its photovoltaic properties. Until recently, various organic small molecules have been synthesized for solar cells. However, most of these molecules have commonly triphenylamine-based structure and are often symmetric [9]. The molecular structure containing heterocyclic system of these type diarylacrylonitriles has been synthesized to investigate their capacity in solar cells as acceptor elsewhere [7, 10-13]. 
Yörür-Göreci et al., JOTCSA. $2016 ; 3(3):$ 439-452.

In this study, photovoltaic properties of a new compound was thoroughly investigated. We achieved comparably a higher $V_{o c}$ as compared to the reference device employing P3HT (poly(3-hexylthiophene-2,5-diyl)) and PCBM blends.

\section{MATERIALS AND METHODS}

All reactions were carried out under nitrogen atmosphere. The solvents were purchased from Merck and dried by standard methods (using anhydrous $\mathrm{CaO}$ and distillation). The reagents were used without further purification from commercial suppliers.

The FT-IR spectra were collected on a Perkin Elmer, Spectrum One Bv 5.0 spectrometer. ${ }^{1} \mathrm{H}$ NMR and ${ }^{13} \mathrm{C}$ NMR spectra were recorded on a Varian Unity Inova Spectrometer (500 $\mathrm{MHz}$ ) using $\mathrm{CDCl}_{3}$. The LC-MS spectra were measured on an Agilent 1200 Infinity HPLC with Agilent 6460 spectrometer.

Melting points of synthesized compounds were determined with Gallenkamp melting point apparatus in open capillaries.

As substrates, ITO (indium tin oxide) glass sheets of $1.5 \mathrm{~cm} \times 1.5 \mathrm{~cm}$, from Kintec Company, Hong kong which has a sheet resistance $<12 \Omega . \mathrm{cm}^{-2}$ were used. The ITO was patterned by etching with an acidic mixture of $\mathrm{HCl}: \mathrm{HNO}_{3}: \mathrm{H}_{2} \mathrm{O}(4.6: 0.4: 5)$ for $30 \mathrm{~min}$. The part of the substrate which forms the contact was covered with a scotch tape to prevent etching. The tape was removed after etching and the substrate was then cleaned using distilled water, acetone and isopropanol in an ultrasonic bath, respectively as described elsewhere [7].

The active layer with 1:0.5 wt ratio was prepared by blending $10 \mathrm{mg}$ of $\mathrm{P} 3 \mathrm{HT}$ and $5 \mathrm{mg}$ of compound 3 (BPCPFA) in $1 \mathrm{~mL}$ of chlorobenzene (CB) and also blends for active layer with $1: 1$ wt ratio was prepared by dissolving $10 \mathrm{mg}$ of P3HT and $10 \mathrm{mg}$ of 3 (BPCPFA) in $1 \mathrm{~mL}$ of chlorobenzene (CB). 
Yörür-Göreci et al., JOTCSA. $2016 ; 3(3):$ 439-452.

For the organic bulk heterojunction solar cells, poly(3,4-ethylenedioxythiophene)poly(styrenesulfonate) (PEDOT:PSS) was deposited on to the ITO coated glass substrate by spin coating at $2000 \mathrm{rpm}$ in air. The PEDOT:PSS layers were annealed in a furnace at $150{ }^{\circ} \mathrm{C}$ for 4 minutes. Active layers of P3HT:CPCPFA were spin-coated onto PEDOT:PSS films at $800 \mathrm{rpm}$ in a glovebox. For some of the devices, thermal annealing of the active layer was done on a hot plate at $120^{\circ} \mathrm{C}$ for 3 minutes. Finally, $100 \mathrm{~nm}$ Al was thermally evaporated as top contact.

All current-voltage (I-V) characteristics of the PV devices were measured (using a Keithley 2400) under nitrogen in a dry glove box just after production. Abet solar simulator, simulating AM1.5 conditions, was used as the excitation source with an input power of $100 \mathrm{~mW} / \mathrm{cm}^{2}$ white-light illumination.

The power conversion efficiencies of the organic solar cells were calculated according to the following equation:

$$
\eta_{A M 1.5}(\%)=\left(\frac{P_{\text {out }}}{P_{\text {In }}}\right) \times 100=\frac{F F V_{o c} J_{s c}}{P_{\text {in }}} \times 100
$$

The percentage efficiency, nAM 1.5, is given by the ratio of the power output (Pout), to the power input from the solar simulator $\left(P_{i n}, 100 \mathrm{~mW} / \mathrm{cm}^{2}\right)$. The output power of a solar cell under illumination is the product of the fill factor (FF), the open-circuit voltage $V_{o c}(V)$ and the current density under short circuit conditions $\mathrm{J}_{\mathrm{sc}}\left(\mathrm{mA} / \mathrm{cm}^{2}\right)$. The fill factor is obtained using the following equation:

$$
F F=\frac{V_{m p p} J_{m p p}}{V_{o c} J_{s c}}
$$

where the maximum power point of the product of the voltage and the current density $\left(V_{\mathrm{mpp}}\right.$ and $\mathrm{J}_{\mathrm{mpp}}$ ) is divided by the product of the open-circuit voltage and the short circuit current.

The current-voltage curves $(J-V)$ of the photovoltaic devices were created by a Keithley 2400 under nitrogen atmosphere. 


\section{Synthesis}

The compound 3 (BPCPFA) studied in this paper was prepared via a three-step procedure (Scheme 1).

The nitrile derivatives (1-3) were obtained by the reaction of appropriate starting materials and characterized by using FT-IR, ${ }^{1} \mathrm{H}$ NMR, ${ }^{13} \mathrm{C}$ NMR, and LC-MS spectral data. All data supported the structures of target molecules (Figure 1-4, see SI).<smiles>N#CCc1ccccc1</smiles><smiles>[Y][C@H](C)OCC</smiles><smiles>N#C/C(=C\c1ccco1)c1ccccc1</smiles>

(1)

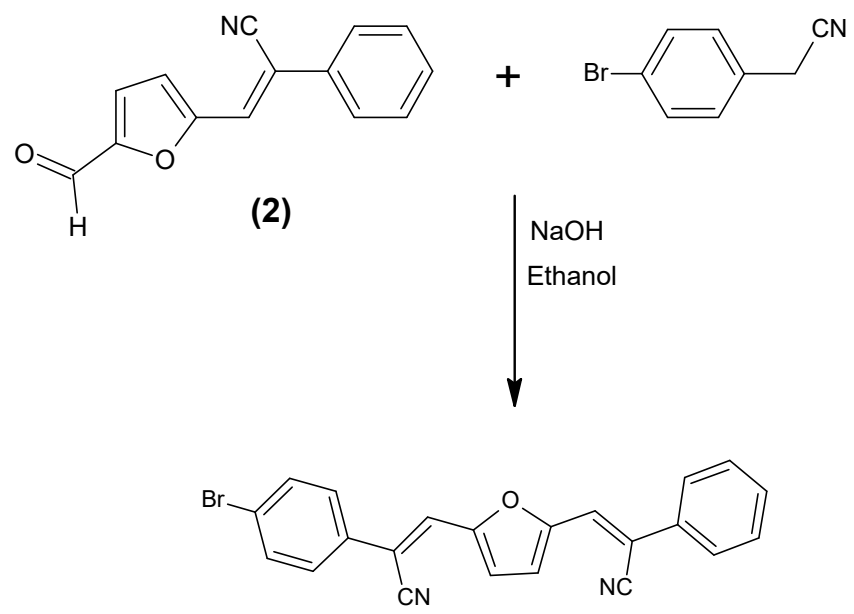

(3, BPCPFA)

Scheme 1. Synthesis of compounds (1-3).

Synthesis of 2-phenyl-3-(furan-2-yl)acrylonitrile (1) [7]

Furan-2-carbaldehyde $(1 \mathrm{mmol})$ and phenylacetonitrile $(1 \mathrm{mmol})$ were dissolved in dry ethanol $(10 \mathrm{~mL})$. After that, sodium hydroxide $(0.1 \mathrm{mmol})$ was added and stirred for 5 min at room temperature under nitrogen atmosphere. The precipitated yellow solid was filtered, washed with ethanol, and recrystallized in $\mathrm{CHCl}_{3}$ to give pure product $\mathbf{1}$ as light yellow crystals [14]. Yield: $97 \%, \mathrm{mp} 86-88^{\circ} \mathrm{C}$. FT-IR (ATR) v, 3098, 3057, 3045, 2214, 1683, $1595 \mathrm{~cm}^{-1} ;{ }^{1} \mathrm{H}$ NMR ( $\left.500 \mathrm{MHz} \mathrm{CDCl}_{3}\right): \delta$ (ppm) 6.55 (m, 1H, furan), 7.32 (brd, J= $7.0 \mathrm{~Hz}, 1 \mathrm{H}$, furan), 7.53 (brs, $1 \mathrm{H},=\mathrm{CH}$ ), 7.58 (brd, $J=3.2 \mathrm{~Hz}, 1 \mathrm{H}$, furan), $7.64(\mathrm{~m}, 3 \mathrm{H}$, 
ArH), $\left.8.12(\mathrm{~d}, J=8.0 \mathrm{~Hz}, 2 \mathrm{H}, \mathrm{ArH}) ;{ }^{13} \mathrm{C} \mathrm{NMR} \mathrm{(125} \mathrm{MHz,} \mathrm{CDCl} 3\right) \delta(\mathrm{ppm}) 112,120,128$, $129,130,134,144,147,148,163,172$. LC-MS m/z: $196[\mathrm{M}]^{+}$(calculated for $\mathrm{C}_{13} \mathrm{H}_{9} \mathrm{NO}$, 195.22).

Synthesis of 2-phenyl-3-(5-formylfuran-2-yl)acrylonitrile (2) [7]

The freshly distilled DMF ( $3 \mathrm{eq}$ ) and $\mathrm{POCl}_{3}$ ( 5 eq) was stirred for $30 \mathrm{~min}$ at $0^{\circ} \mathrm{C}$, under nitrogen. Compound $1(0.5 \mathrm{~g}, 1.49 \mathrm{mmol})$ in $\mathrm{CH}_{2} \mathrm{Cl}_{2}(5 \mathrm{~mL})$ was added to the mixture and stirred for $12 \mathrm{~h}$ at room temperature [15]. The obtained solid was collected by filtration and purified by column chromatography on silica gel using ethyl acetate/hexane (5:1). A dark yellow solid of compound 2 was obtained. Yield: $83 \%, \mathrm{mp} 127-129^{\circ} \mathrm{C}$. FTIR (ATR) v, 3098, 3062, 3032, 2222, 1667, $1596 \mathrm{~cm}^{-1} ;{ }^{1} \mathrm{H} \mathrm{NMR}\left(500 \mathrm{MHz} \mathrm{CDCl}_{3}\right): \delta$ (ppm) 7.38 (d, J= $7.0 \mathrm{~Hz}, 1 \mathrm{H}$, furan), 7.47 (brd, $J=3.2 \mathrm{~Hz}, 1 \mathrm{H}$, furan), $7.49(\mathrm{~m}, 3 \mathrm{H}$, ArH) , 7.50 (brs, $1 \mathrm{H},=\mathrm{CH}), 7.67(\mathrm{~d}, \mathrm{~J}=8.0 \mathrm{~Hz}, 2 \mathrm{H}, \mathrm{ArH}), 9.73(\mathrm{~s}, 1 \mathrm{H},-\mathrm{CHO}) ;{ }^{13} \mathrm{C} N M R$ $\left(125 \mathrm{MHz}, \mathrm{CDCl}_{3}\right) \delta$ (ppm) 113,115, 117, 122, 126, 129, 130,132, 133, 152, 154, 178. LC-MS m/z: $224[M]^{+}$(calculated for $\mathrm{C}_{14} \mathrm{H}_{9} \mathrm{NO}_{2}, 223.23$ ).

2-(4-Bromophenyl)-3-\{5-[2-cyano-2-phenylethenyl]furan-2-yl\}acrylonitrile (3, BPCPFA)

The compound $\mathbf{3}$ (BPCPFA) synthesized from compound $\mathbf{2}$ and 4bromophenylacetonitrile starting materials according to the same procedure with compound 1 [7, 15]. Light-orange solid. Yield: 97\%, mp 159-161 ${ }^{\circ} \mathrm{C}$. FT-IR (ATR) v, 3088, 3051, 3029, 2209, 1675, $1596 \mathrm{~cm}^{-1} ;{ }^{1} \mathrm{H}$ NMR (500 MHz, CDCl 3 ): $\delta$ (ppm) 7.42 (s, $2 \mathrm{H}, 2 \times-\mathrm{C}=\mathrm{CH}), 7.43-7.49(\mathrm{~m}, 5 \mathrm{H}, \mathrm{ArH}), 7.55-7.62(\mathrm{~m}, 4 \mathrm{H}, \mathrm{ArH}), 7.69(\mathrm{~d}, J=7.2 \mathrm{~Hz}$, $2 \mathrm{H}, \mathrm{ArH}) .{ }^{13} \mathrm{C}-\mathrm{NMR}\left(125 \mathrm{MHz}, \mathrm{CDCl}_{3}\right): \delta$ (ppm) 109, 111, 117, 118, 126, 127, 129, 130, 136, 152. LC-MS m/z: $402[M]^{+}$(calculated for $\mathrm{C}_{22} \mathrm{H}_{13} \mathrm{BrN}_{2} \mathrm{O}, 401.25$ ).

\section{RESULTS AND DISCUSSION}

\section{Theoretical calculation of HOMO-LUMO}

HOMO and LUMO energies of the compound $\mathbf{3}$ have been calculated. The calculations were saved using Gaussian 09 W software [16] by DFT/B3LYP method with 6-31 G(d) basis set. Optimized molecular structure and energy of the BPCPFA are given in Figure 5. 


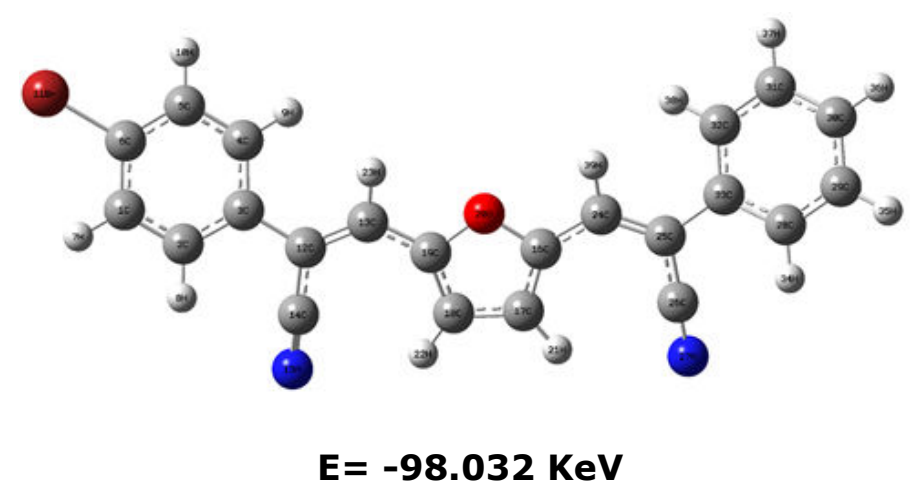

Figure 5. Optimized molecular structure and energy of BPCPFA.

HOMO-LUMO energies are crucial in order to explain the chemical reactivity and stability of molecule. Determination of the HOMO-LUMO level alignment between the donor and acceptor is crucial to designate whether there will be an efficient charge transfer or not $[17,18]$. The HOMO-LUMO energy gap of BPCPFA is shown in Figure 6. HOMO-LUMO energy band for new compound $\mathbf{3}$ is $2.83 \mathrm{eV}$, so it is possible that charge transfer interaction may easily occur in the molecule.

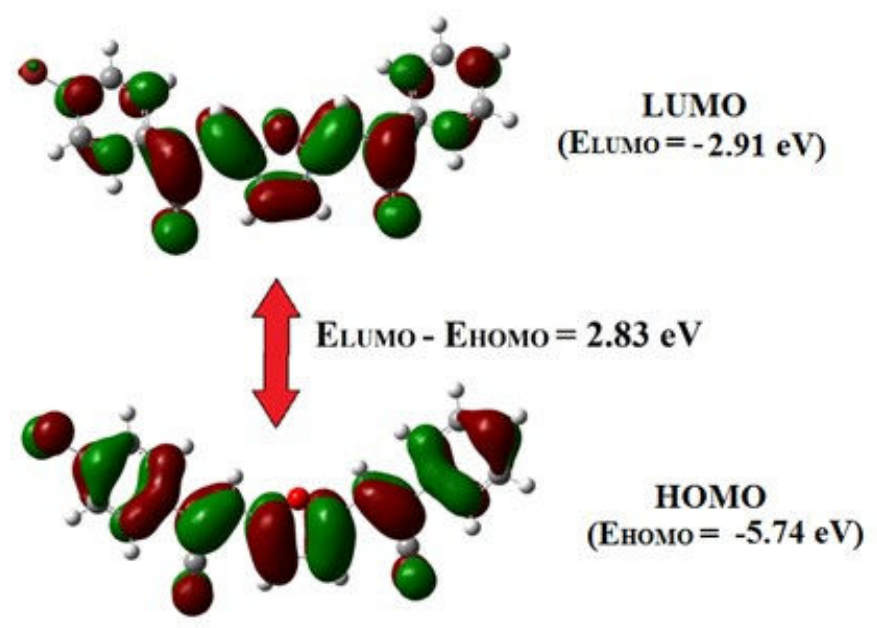

Figure 6. HOMO-LUMO energy diagrams for compound 3, BPCPFA.

The theoretical HOMO-LUMO levels of P3HT are $-4.32 \mathrm{eV}$ and $-2.3 \mathrm{eV}$, whereas the values of PCBM are $-5.66 \mathrm{eV}$ and $-3.02 \mathrm{eV}$, respectively [19]. In calculations performed for BPCPFA, the HOMO and LUMO energies were calculated to be $-5.74 \mathrm{eV}$ and $-2.91 \mathrm{eV}$. It can be concluded that since the LUMO level of P3HT lies above the BPCPFA, and there is an energy difference of $0.61 \mathrm{eV}$ between their LUMOs which is more than $0.3 \mathrm{eV}$, a charge transfer can be possible between P3HT and BPCPFA. Therefore, P3HT was 
Yörür-Göreci et al., JOTCSA. $2016 ; 3(3):$ 439-452.

evaluated as a donor whereas BPCPFA was generated as an acceptor in the organic solar cells.

\section{Photovoltaic Studies}

Photovoltaic performance of the devices employing active layers of P3HT:BPCPFA with different weight ratios (1:0.5 and 1:1 wt) have been studied. A reference device in which no BPCPFA employed was also studied to understand whether BPCPFA has an acceptor role in the device. As can be seen from Figure 7a, devices comprising of 1:0.5 wt donor acceptor ratio showed a short-circuit current density $\left(\mathrm{J}_{\mathrm{sc}}\right)$ of $0.124 \mathrm{~mA} / \mathrm{cm}^{2}$, an opencircuit voltage $\left(\mathrm{V}_{\mathrm{oc}}\right)$ of $960 \mathrm{mV}$ and a fill factor $(\mathrm{FF})$ of 0.24 was calculated which led to a power conversion efficiency (PCE) of $0.029 \%$.

We achieved a $\mathrm{J}_{\mathrm{sc}}$ of $0.206 \mathrm{~mA} / \mathrm{cm}^{2}$ and a $\mathrm{V}_{\mathrm{oc}}$ of $958 \mathrm{mV}$, and an FF of 0.26 which led to a PCE of $0.051 \%$ for the devices containing of $1: 1$ wt donor acceptor ratio (Figure $7 \mathrm{~b}$ ).

There is an ongoing debate on the nature of the open-circuit voltage in literature, however $V_{0 c}$ value is known to be proportional to the difference between the HOMO of the donor and the LUMO of the acceptor. In the best case, we achieved a Voc of $0.960 \mathrm{~V}$.

Voc value can be calculated by the following equation $[20,21]$ :

$$
V_{\text {oC }}=(1 / e)\left[\left(E_{\text {donor }} \text { HOMO }\right)-\left(E_{\text {acceptorLUMO })}\right]-0.3 \mathrm{~V}\right.
$$

Figure 7c displays the $J-V$ curves of the reference P3HT device $\left(J_{\mathrm{sc}}=0.017 \mathrm{~mA} / \mathrm{cm}^{2}, V_{\text {oc }}\right.$ $=105 \mathrm{mV}$ and $\mathrm{FF}=0.28$ ). 

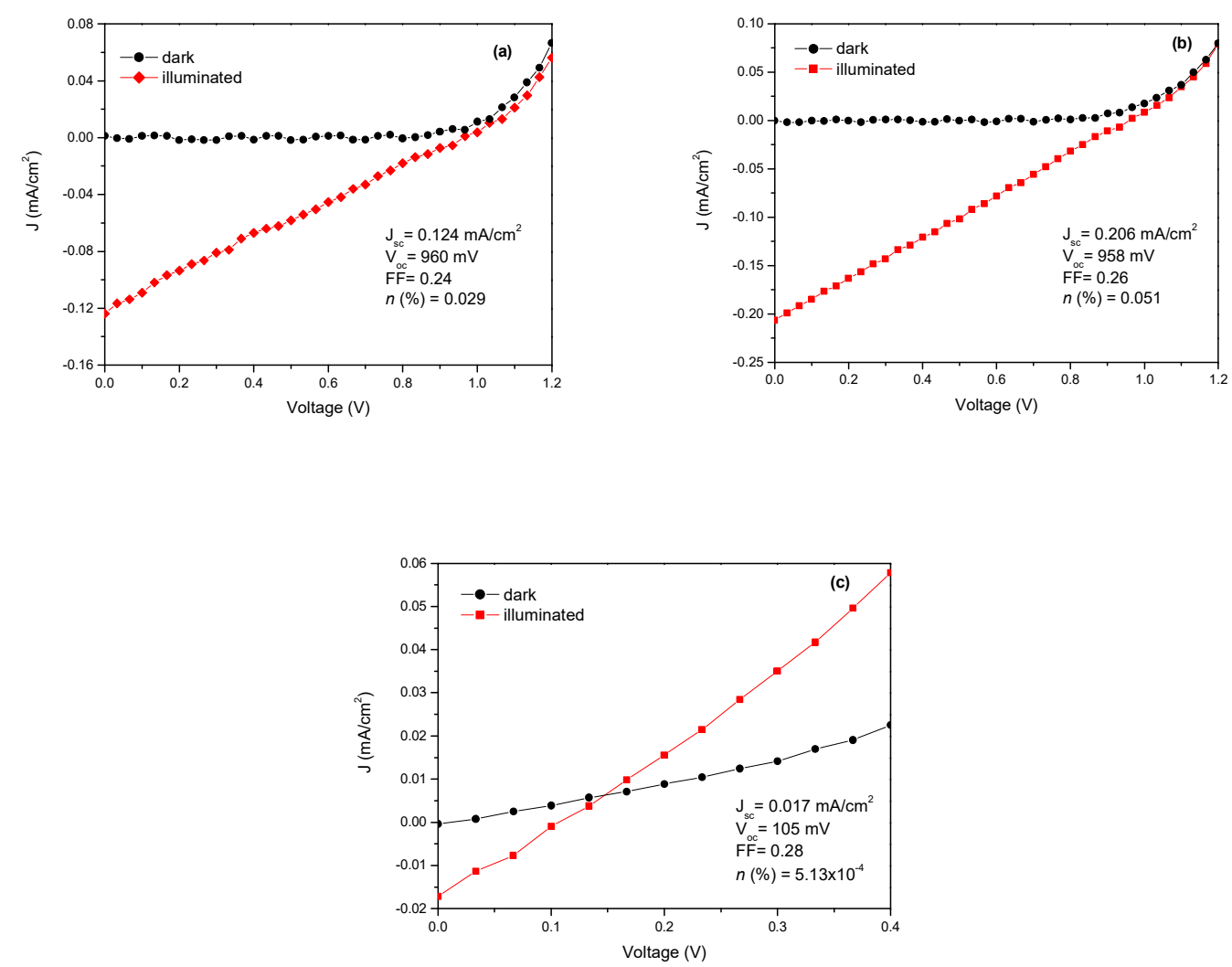

Figure 7. J-V curves of (a) devices with active layers of $1: 0.5$ donor-acceptor ratio, (b) $1: 1$ donor-acceptor ratio, (c) $J-V$ curves of a reference device. 
Briefly, the performance of the device created by using BPCPFA is approximately 7 times more than the performance of created by using $\mathrm{P} 3 \mathrm{HT}$ reference.

\section{CONCLUSIONS}

In conclusion, a new diarylacrylonitrile derivative (BPCPFA) was used as an electron acceptor in organic solar cells and its synthetic and device performance characteristics were fully investigated. The photovoltaic performance of this compound was investigated using both theoretical and experimental techniques. The acceptor type molecules for photovoltaic use are off great interest. Polymer or small molecule acceptors have several advantages such as good absorption in the visible region and a higher LUMO energy level than PCBM, which in turn leads to a high open-circuit voltage ( $\mathrm{V} O \mathrm{OC})$. We achieved a $\mathrm{V}$ oc of $960 \mathrm{mV}$, which is higher than that of the conventional bulk heterojunction organic solar cells comprising of $\mathrm{P} 3 \mathrm{HT}$ and PCBM.

The offset of HOMO and LUMO levels between donor and the acceptor is very important to get efficient charge transfer. The offset of HOMO-LUMO energy levels should be almost $0.3 \mathrm{eV}$. The theoretical HOMO-LUMO energy levels of BPCPFA are very close to that of PCBM which is most used as an electron acceptor materials in organic photovoltaics.

Based on all the data of our study, further studies will be carried on by changing the device parameters and molecular structure.

\section{ACKNOWLEDGEMENT}

We thank Assoc.Prof. Halil Gokce at Giresun University for his fruitful discussions about Gaussian 09 W software . 


\section{REFERENCES}

1. Bloking JT, Han X, Higgs AT, Kastrop JP, Pandey L, Norton JE, Risko C, Chen CE, Brédas JL, McGehee MD, Sellinger A. Solution-processed organic solar cells with power conversion efficiencies of $2.5 \%$ using benzothiadiazole/imide-based acceptors. Chemistry of Materials. 2011;23:5484-90. DOI: $10.1021 / \mathrm{cm} 203111 \mathrm{k}$.

2. Gunes S, Neugebauer H, Sariciftci NS. Conjugated polymer-based organic solar cells. Chemical Reviews. 2007;107: 1324-38. DOI:10.1021/cr050149z.

3. Brabec CJ, Gowrisanker S, Halls JJM, Laird D, Jia S, Williams SP. Polymer-fullerene bulkheterojunction solar cells. Advanced Materials. 2010;22:3839-56. DOI: $10.1002 /$ adma.200903697.

4. Linac $Y$ and Zhan $X$. Non-fullerene acceptors for organic photovoltaics: an emerging horizon. Materials Horizons. 2014;1: 470-88. DOI: 10.1039/c4mh00042k.

5. Babu DD, Gachumale SR, Anandan S, Adhikari AV. New D-n-A type indole based chromogens for DSSC: design, synthesis and performance studies. Dyes and Pigments. 2015;112:183-91. DOI:10.1016/j.dyepig.2014.07.006.

6. Liang Y, Xu Z, Xia J, Tsai ST, Wu Y, Li G, Ray C, Yu L. For the bright future-bulk heterojunction polymer solar cells with power conversion efficiency of $7.4 \%$. Advanced Energy Materials. 2010;22:135-38. DOI: 10.1002/adma.200903528.

7. Kazici M, Bozar S, Aydin-Yuksel S, Ongul F, Gokce H, Gunes S, Yorur-Goreci C. Nanotechnology theoretical and experimental investigations of a 2-(4-chlorophenyl)-3- $\{[5-$ (2-cyano-2- phenylethenyl)]furan-2-yl\}acrylonitrile molecule as a potential acceptor in organic solar cells. Nanotechnology. 2016;27:234003(9pp). DOI:10.1088/09574484/27/23/234003.

8. Eftaiha AF, Sun JP, Hill IG, Welch GC. Recent advances of non-fullerene, small molecular acceptors for solution processed bulk heterojunction solar cells. Journal of Materials Chemistry A. 2014;2:1201-13. DOI: 10.1039/C3TA14236A.

9. Yue $Y$, Kang, J, Yu M. The synthesis and photophysical properties of novel triphenylamine derivatives containing $\alpha$, B-diarylacrylonitrile. Dyes and Pigments. 2009;83:72-80. doi:10.1016/j.dyepig.2009.03.014.

10. Mishra A and Bäuerle P. Small molecule organic semiconductors on the move: promises for future solar energy technology. Angewandte Chemie International Edition. 2012;51: 202067. DOI:10.1002/anie.201102326.

11. Lu SL, Yang MJ, Bai FL. Synthesis, electrochemical, and optical properties of a novel PPV/PPE block-copolymer. Macromolecular Rapid Communications. 2004;25:968-71. DOI: $10.1002 /$ marc.200400004.

12. Xu Y, Zhang H, Li F, Shen F, Wang H, Li X, Yu Y, Ma Y. Supramolecular interaction-induced self-assembly of organic molecules into ultra-long tubular crystals with wave guiding and amplified spontaneous emission. Journal of Materials Chemistry. 2012;22:1592-97. DOI: $10.1039 /$ C1JM14815].

13. Nagamatsu S, Oku S, Kuramoto K, Moriguchi T, Takashima W, Okauchi T, Hayase S. Longterm air stable n-channel organic thin-film transistors using 2,5-difluoro-1,4-phenylenebis $\{2-[4-($ trifluoromethyl)phenyl]acrylonitrie\}. Applied Materials and Interfaces. 2014;6:3847-52. DOI: 10.1021/am.404549e. 
14. Ying A, Wang L, Qiu F, Hu H, Yang J. Magnetic nanoparticle supported amine: an efficient and environmental benign catalyst for versatile Knoevenagel condensation under ultrasound irradiation. Comptes Rendus Chimie. 2015;18:223-32. DOI:10.1016/j.crci.2014.05.012.

15. Yang C, Chen H, Chuang Y, Wu C, Chen C, Liao S, Wang T. Characteristic of triphenylamine-based dyes with multiple acceptors in application of dye-sentized solar cells. Journal of Power Sources. 2009;188: 627-34. DOI:10.1016/j.powsour.2008.12.026.

16. Becke AD. Density functional thermochemistry: III. The role of exact exchange. Journal of Chemical Physics. 1993;98:5648-52. DOI:10.1063/1.464913.

17. Karthighaa S, Kalainathana S, Raob KUM, Hamadac F, Yamadad M, Kondoe Y. Synthesis, growth, structural, optical, luminescence, surface and HOMO-LUMO analysis of 2-[2-(4cholro-phenyl)-vinyl]-1-methylquinolinium naphthalene-2-sulfonate organic single crystals grown by a slow evaporation technique. Journal of Crystal Growth. 2016;436:113-24. DOI: $10.1016 / j$.jcrysgro.2015.11.028.

18. Kim BG, Xiao M, Chen C, Ie Y, Coir EW, Hashemi H, Aso Y, Green PF, Kieffer J, Kim J. Energy level modulation of HOMO-LUMO, and band-gap in conjugated polymers for organic photovoltaic applications. Advanced Functional Materials. 2013;23:439-45. DOI: $10.1002 / a d f m .201201385$.

19. Xie XH, Shen W, He RX, Li M. A density functional study of furofuran polymers as potential materials for polymer solar cells. Bulletin Korean Chemical Society. 2013;34: 2995-04. DOI: $10.5012 /$ bkcs.2013.34.10.2995.

20. Scharber MC. On the efficiency limit of conjugated polymer: fullerene-based bulk heterojunction solar cells. Advanced Materials. 2016;28:1994-01. DOI: $10.1002 / a d m a .201504914$.

21. Elumalai NK and Ashraf U. Open circuit voltage of organic solar cells: an in-depth review. Energy and Environmental Science. 2016;9:391-10. DOI: 10.1039/c5ee02871j. 


\section{Türkçe Öz ve Anahtar Kelimeler}

\section{Fotovoltaik Performans Gösteren Yeni bir Akrilonitril Türevi}

Çiğdem Yörür-Göreci*,Mehmet Kazici, Sinem Bozar, Zulal Demir, Abdullah Toraman, Fatih Ongul, Abid Ali, Serap Güneş

Öz: Yeni bir akrilonitril türevi olan 2-(4-bromofenil)-3-\{5-[2-siyano-2-feniletenil]furan-2il\}akrilonitril (BPCPFA, 3) bileşiğinin organik güneş pillerinde uygulanma potansiyeli vardır ve üç kademeli bir tepkimeyle sentez edilmiştir. Bu adımlar sırasında sentezlenen moleküllerin yapıları çeşitli spektral analizler kullanılarak karakterize edilmiştir. BPCPFA yeni nesil organik güneş pillerinde elektron alıcı molekül olarak incelenmiştir. Teorik tahminler ve fotovoltaik performans için deneysel çalışmalar da yürütülmüştür. Bu sonuçlara dayanarak, BPCPFA'nın uzamış konjuge sistemiyle iyi ve ümit vaat eden bir fotovoltaik performans $\left(V_{o c}=0,96 \mathrm{~V}\right)$ gösterdiği sonucuna varılmıştır.

Anahtar kelimeler: Konjuge sistemler; nitriller; organik güneş pilleri; fotovoltaikler.

Sunulma: 15 Temmuz 2016. Düzeltme: 19 Eylül 2016. Kabul: 30 Eylül 2016. 
